\title{
Influence of cytokines on Dmt1 iron transporter and ferritin expression in insulin-secreting cells
}

\author{
S Lortz, S Schröter ${ }^{\dagger}$, V Stückemann ${ }^{\ddagger}$, I Mehmeti and S Lenzen
}

Hannover Medical School, Institute of Clinical Biochemistry, 30623 Hannover, Germany ('S Schröter is now at Department of Neurobiology, Max Planck Institute for Biophysical Chemistry, 37077 Göttingen, Germany)

( ${ }^{\ddagger} V$ Stückemann is now at Twincore Centre for Experimental and Clinical Infection Research, 30625 Hannover, Germany and Department of Gastroenterology, Hepatology and Endocrinology, Hannover Medical School, 30623 Hannover, Germany)

Correspondence should be addressed to S Lortz Email

Lortz.Stephan

@mh-hannover.de

\begin{abstract}
Free intracellular ferrous iron $\left(\mathrm{Fe}^{2+}\right)$ is essential for the generation of the extremely toxic hydroxyl radicals, which contribute to $\beta$-cell destruction by cytokines. Therefore the expression of the different divalent metal transporter 1 (Dmt1) isoforms and ferritin (Ft) subunits, responsible for iron import and chelation, was analyzed under pro-inflammatory conditions (IL1 $\beta$ alone or together with TNF $\alpha+$ IFN $\gamma$ ). The Dmt1 isoforms (1A/1B and + IRE/ - IRE) and the total Dmt1 expression in insulin-producing cells (RINm5F and INS-1E), in primary rat islets and, for comparison, in the neuroendocrine PC12 cell line were quantified by qRT-PCR. In addition, the expression of the light $(\mathrm{L}-\mathrm{Ft})$ and heavy $\mathrm{Ft}(\mathrm{H}-\mathrm{Ft})$ subunits and the mitochondrial $F t$ isoform ( $M t f t$ ) in insulin-producing cells under control conditions and after cytokine treatment was estimated. The 1B isoform was the predominant Dmt1 mRNA in all insulin-producing cells, accounting for almost $100 \%$ of the $1 \mathrm{~A} / 1 \mathrm{~B}$ isoform expression. For the IRE variants, + IRE expression was higher than - IRE expression. Pro-inflammatory cytokines accelerated the expression of Dmt1 isoforms significantly with an overall 2.5- to 3-fold increase in the total Dmt1 expression. In contrast, the expression of the iron-buffering ferritin subunits L- and H-Ft was unaffected by IL $1 \beta$ and only slightly induced by the cytokine mixture. Mtft expression was also not increased. Dmt1 expression was significantly elevated through pro-inflammatory cytokines, whereas Ft expression was marginally increased. This imbalance between the increased iron transport capacity and the almost unaffected iron storage capacity can foster cytokine-mediated formation of hydroxyl radicals and thus pro-inflammatory cytokine toxicity through elevated free iron concentrations.
\end{abstract}
Key Words
- insulin-secreting cells
- iron transport and storage
- Dmt1
- ferritin
- reactive oxygen species
- pro-inflammatory cytokines
- Haber-Weiss reaction

\section{Introduction}

The destruction of insulin-secreting $\beta$-cells by infiltrating immune cells is mediated via soluble pro-inflammatory cytokines, in particular interleukin $1 \beta$ (IL1 $\beta$ ), tumor necrosis factor- $\alpha$ (TNF $\alpha)$, and interferon- $\gamma$ (IFN $\gamma)$
(Jörns et al. 2005, Thomas et al. 2009). Activation of the respective receptors initiates the intracellular signaling cascades leading ultimately to $\beta$-cell dysfunction and apoptosis (Cnop et al. 2005, Novotny et al. 2012). 
One major component of this process is the oxidative destruction of cellular structures by an increased generation of reactive oxygen species (ROS), especially of highly toxic hydroxyl radicals (Gurgul-Convey et al. 2011, Mehmeti et al. 2011a). Hydroxyl radicals are formed in the Haber-Weiss reaction in the presence of catalytically active free ferrous iron $\left(\mathrm{Fe}^{2+}\right)$ from intracellular hydrogen peroxide (Halliwell \& Gutteridge 2007).

Circulating iron is sequestered by transferrin within the bloodstream. Through interaction with the transferrin receptors this transferrin-bound iron can enter the cell by endocytosis. The subsequent transport step from the endosome to the cytosol is mediated by the divalent metal transporter 1 (Dmt1), which is expressed in four known isoforms, resulting from two different $5^{\prime}$-variants, called $1 \mathrm{~A}$ and $1 \mathrm{~B}$, and two $3^{\prime}$-variants, which are different in their 3'-translated and UTR, containing or not an ironresponsive element (+IRE/-IRE; Gunshin et al. 1997, Hubert \& Hentze 2002, MacKenzie et al. 2008). These elements are important for the regulation of the Dmt1 expression by influencing mRNA stability (Galy et al. 2008) and each of these $3^{\prime}$-variants can occur with both $5^{\prime}$-types of RNA. Due to the central role of iron for the synthesis of heme prosthetic groups and iron-sulfur clusters, a high portion is further transferred into mitochondria, although the exact transport mechanisms are only poorly characterized (Horowitz \& Greenamyre 2010).

In order to avoid an excess of free iron in the cell, in the form of the so-called labile iron pool (LIP), cellular iron homeostasis is precisely balanced by regulating iron import, its intracellular handling, and chelation (Pantopoulos et al. 2012). Intracellular iron storage and chelation are mediated by ferritin (Ft), which prevents in this way an excess of free intracellular iron and its damaging effects (Hentze et al. 2004). Ft in its cytosolic form consists of two different subunits, called the $\mathrm{H}$ (heavy) and L (light) subunits. Twenty-four of these subunits form, in a variable ratio of H:L subunits, the apoferritin molecule (Harrison \& Arosio 1996). At variance from the cytosolic Ft molecule, the mitochondrial Ft (Mtft) molecule has a homopolymeric structure with a high homology to the Ft-H molecule (Levi et al. 2001).

Pro-inflammatory cytokines, however, favor pro-oxidative conditions and the generation of hydroxyl radicals in insulin-secreting cells (Lortz et al. 2000). The extremely low expression of the hydrogen peroxide-inactivating enzymes catalase and glutathione peroxidase, together with a relatively high superoxide dismutase expression (Lenzen et al. 1996, Tiedge et al. 1997, Lenzen 2008), leads to an accumulation of hydrogen peroxide under the influence of pro-inflammatory cytokines (Gurgul-Convey et al. 2011). Although catalase expression in human islets (Welsh et al. 1995) is somewhat higher than that in rodent islets (Lenzen et al. 1996, Tiedge et al. 1997, Lenzen 2008), the catalase activity of human $\beta$-cells is, when compared with other tissues, very low (for discussion see Lenzen (2008)) and therefore similar damaging effects of ROS could be observed in human islets (Benhamou et al. 1998).

Together with an induction of iron import via Dmt1 through pro-inflammatory cytokines (Hansen et al. 2012), this would support hydroxyl radical formation, promoting serious damage to many cellular structures (Mehmeti et al. 2011b, Hansen et al. 2014). We therefore characterized the influence of pro-inflammatory cytokines on the expression of the different Dmt1 isoforms and whether enhanced Dmt1 expression could be compensated, probably by increased expression of the iron-chelating protein $\mathrm{Ft}$.

\section{Materials and methods}

\section{Tissue culture of insulin-producing cells}

Insulin-producing RINm5F tissue culture cells were cultured in RPMI-1640 medium supplemented with $10 \mathrm{mM}$ glucose, $10 \%(\mathrm{v} / \mathrm{v})$ FCS, penicillin, and streptomycin as described previously (Lenzen et al. 1996, Tiedge et al. 1997). Insulin-secreting INS-1E cells (kindly provided by Prof. C Wollheim) were cultured as previously described (Asfari et al. 1992). The neuroendocrine PC12 cells were cultured in RPMI-1640 medium supplemented with $10 \mathrm{mM}$ glucose, $5 \%(\mathrm{v} / \mathrm{v})$ FCS, 10\% (v/v) horse serum, penicillin, and streptomycin (Greene \& Tischler 1976). All cell lines were cultured at $37^{\circ} \mathrm{C}$ in a humidified atmosphere of $5 \% \mathrm{CO}_{2}$.

\section{Rat islet isolation}

Pancreatic islets were isolated from 250 to $300 \mathrm{~g}$ adult male Lewis rats by collagenase digestion, separated by Ficoll gradient, and handpicked under a stereo microscope (Tiedge et al. 1997). Isolated islets were cultured overnight in RPMI-1640 medium supplemented with $5 \mathrm{mM}$ glucose, $10 \%$ FCS, penicillin, and streptomycin at $37^{\circ} \mathrm{C}$ in a humidified atmosphere of $5 \% \mathrm{CO}_{2}$.

\section{Exposure to pro-inflammatory cytokines}

The cells were seeded in $6 \mathrm{~cm}$ tissue culture plates at a density of $1 \times 10^{6}$ cells and allowed to attach for a period of $24 \mathrm{~h}$. Thereafter the cells were exposed to

Published by Bioscientifica Ltd. 
$600 \mathrm{U} / \mathrm{ml}$ human IL1 $\beta$ or a combination of cytokines (cytokine mixture) consisting of $60 \mathrm{U} / \mathrm{ml} \mathrm{IL1 \beta ,} 185 \mathrm{U} / \mathrm{ml}$ human TNF $\alpha$, and $14 \mathrm{U} / \mathrm{ml}$ IFN $\gamma$ (PromoCell, Heidelberg, Germany) for the indicated incubation times.

\section{Hypoxic incubation}

For incubation under hypoxic conditions, the cells were cultured $24 \mathrm{~h}$ after seeding at $37^{\circ} \mathrm{C}$ in a humidified atmosphere of $1 \% \mathrm{O}_{2}$ balanced with $\mathrm{N}_{2}$ for hypoxia for the indicated incubation times ( 6 and $24 \mathrm{~h}$ hypoxia or $24 \mathrm{~h}$ hypoxia followed by $6 \mathrm{~h}$ normoxia). Hypoxia was generated in an oxygen-regulated incubator (CB210 incubator with $\mathrm{O}_{2}$ control option, Binder, Tuttlingen, Germany). After incubation, total RNA was isolated immediately.

\section{Real-time quantitative RT-PCR}

Total RNA was isolated as previously described (Chomczynski \& Sacchi 1987). For cDNA synthesis, random hexamers were used to prime the reaction of the RevertAid H- M-MuLV reverse transcriptase (Fermentas, St Leon-Rot, Germany). QuantiTect SYBR Green technology (Qiagen), which uses a fluorescent dye that only binds doublestranded DNA, was employed. The reactions were carried out using the Opticon Realtime-PCR-System (Bio-Rad). The samples were first denatured at $94^{\circ} \mathrm{C}$ for $3 \mathrm{~min}$, followed by 40 PCR cycles comprising a melting step at $94{ }^{\circ} \mathrm{C}$ for $30 \mathrm{~s}$, an annealing step at $62^{\circ} \mathrm{C}$ for $30 \mathrm{~s}$, and an extension step at $72{ }^{\circ} \mathrm{C}$ for $30 \mathrm{~s}$. Optimal parameters for the PCRs were empirically defined and the purity and specificity of the amplified PCR product for each experiment was verified by melting curve analysis. All transcripts showed $C_{\mathrm{t}}$-values, which were at least ten $C_{\mathrm{t}}$-values lower than the values for blanks. Each PCR amplification was carried out in triplicate. The primer sequences are listed in Supplementary Table 1, see section on supplementary data given at the end of this article. Data are expressed as relative gene expression after normalization to the housekeeping gene $\beta$-actin using the Qgene96 (Institute of Biochemistry and Genetics, Research Group Cardiovascular Genetics, University of Basel, Switzerland) and LineRegPCR (Heart Failure Research Center, Amsterdam, the Netherlands) software.

\section{Western blot analyses}

After $48 \mathrm{~h}$ of incubation, whole-cell extracts were sonified in ice-cold PBS on ice for $15 \mathrm{~s}$ at $60 \mathrm{~W}$ with a Braun-Sonic 125 sonifier. Protein content was determined by the BCA assay (Pierce, Rockford, IL, USA). $20 \mu \mathrm{g}$ protein per lane was fractionated by $12.5 \%$ SDS-PAGE and transferred to polyvinylidene fluoride membranes. Nonspecific binding sites of the membranes were blocked by $5 \%$ non-fat dry milk for $1 \mathrm{~h}$ at room temperature. Then the membranes were incubated overnight at $4{ }^{\circ} \mathrm{C}$ with the specific primary antibody (Dmt1, sc-30120, diluted 1:200; actin, sc-1615, 1:250, Santa Cruz Biotechnology). The excess of primary antibody was removed by three washes with wash buffer (PBS, 0.1\% Tween 20, 0.1\% BSA), subsequently the membrane was incubated with the peroxidase-labeled secondary antibodies at a dilution of 1:20 000 at room temperature for $1 \mathrm{~h}$. The protein bands were visualized by chemiluminescence using the ECL detection system (GE Life Sciences, Freiburg, Germany). The intensity of the bands was quantified through densitometry with the Gel-Pro Analyzer 6.0 program (Media Cybernetics, Silver Spring, MD, USA).

\section{Statistical analyses}

Data are expressed as mean \pm s.E.M. Statistical analyses were performed using ANOVA plus Bonferroni's test for multiple comparisons (Graphpad, San Diego, CA, USA).

\section{Results}

\section{Expression of the different Dmt1 isoforms in insulin-producing cells and primary rat islets}

For the quantification of the four characterized Dmt1 isoforms in different insulin-producing cell lines and primary rat islets, qRT-PCR analyses with isoform-specific primers were carried out. The $1 \mathrm{~B}$ transporter isoform was the predominately expressed Dmt1 isoform in all insulin-producing cell lines and rat pancreatic islets, responsible for almost $100 \%$ of total Dmt1 expression (Fig. 1). In contrast to this, expression of the $1 \mathrm{~A}$ isoform was extremely low in all investigated insulin-producing cells and accounted for $<1 \%$ of the total Dmt 1 expression. Regarding the +/- IRE splice variants, the expression level of +IRE variant was markedly higher than that of -IRE in both RINm5F and INS-1E cells (approximately $40-60 \%+$ IRE and 20\% - IRE). However, in primary rat islets both variants were almost equally expressed (approximately 30\% each, Fig. 1), which probably results from a different expression pattern of Dmt1 in non-beta islet cells.

Investigation of the neuroendocrine PC12 cell line showed a completely different Dmt1 expression profile. Although the expression of the $1 \mathrm{~B}$ variant was also predominant in PC12 cells, the expression of the 1A transcript represented up to $40 \%$ of the total Dmt1

Published by Bioscientifica Ltd 

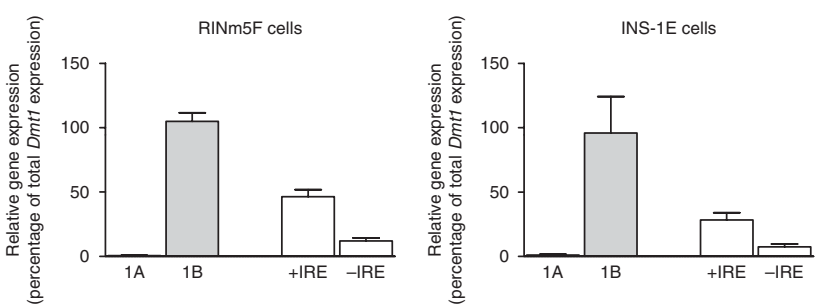

Figure 1

Expression of the different Dmt1 isoforms in insulin-producing cells, primary rat islets, and PC12 cells. Total RNA was isolated $24 \mathrm{~h}$ after culture under control conditions from RINm5F cells, INS-1 cells, primary rat islets, and PC12 cells. The gene expression of all investigated Dmt1 isoforms was analyzed by qRT-PCR with Dmt1 1A, 1B (grey bars), + IRE and - IRE

expression, a multiple of that in insulin-producing cells. The proportion of the + IRE transcript of total DMT1 expression was nearly $80 \%$ and therefore twofold higher than in islets or INS-1E cells, whereas the -IRE proportion of total DMT1 expression was $<20 \%$ (Fig. 1).

\section{Effects of hypoxia on Dmt1 gene expression in insulin-producing RINm5F cells}

Under oxygen deprivation, a number of signaling pathways involved in systemic iron transport, cellular
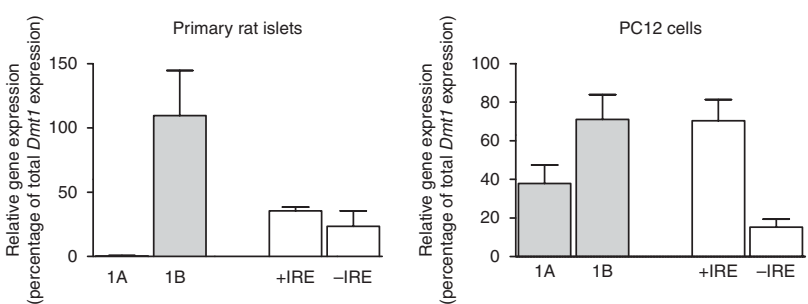

(white bars)-specific primers and with a primer pair detecting a Dmt1 consensus sequence. The expression levels were normalized to the housekeeping gene $\beta$-actin. The gene expression of total Dmt1 in each cell type was set as $100 \%$. Data are mean \pm S.E.M. from 6 to 14 individual experiments.

iron supply, and metabolism are activated. Therefore, the effects of temporary hypoxia on Dmt1 isoform expression were analyzed.

Incubation of RINm5F cells for $6 \mathrm{~h}$ at $1 \% \mathrm{O}_{2}$ had no effect on the expression of all investigated Dmt1 isoforms or on total Dmt1 expression (Fig. 2). Although an extension of the incubation time to $24 \mathrm{~h}$ resulted in a threefold induction of Dmt1 1A, while the expression of $1 \mathrm{~B}$, of $+/-\mathrm{IRE}$, and of the total Dmt1 remained unchanged. A transient hypoxic period of $24 \mathrm{~h}$ followed by $6 \mathrm{~h}$ under normoxic conditions increased Dmt1 1A
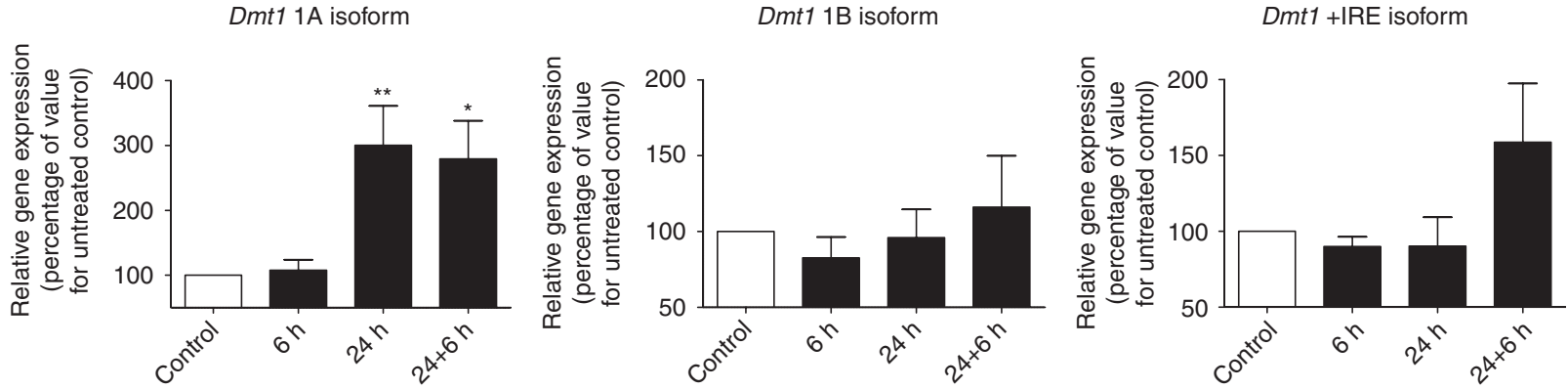

Dmt1-IRE isoform

Total Dmt1 experssion
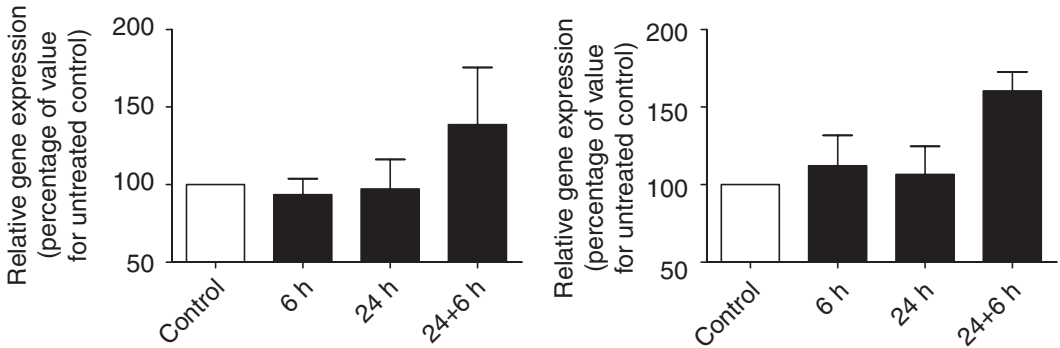

\section{Figure 2}

Effects of hypoxia on Dmt1 gene expression in insulin-producing RINm5F cells. RINm5F cells were incubated for up to $24 \mathrm{~h}$ with $1 \% \mathrm{O}_{2}$, for $24 \mathrm{~h}$ under hypoxic conditions followed by a $6 \mathrm{~h}$ normoxic incubation $(24+6 \mathrm{~h})$ or for $24 \mathrm{~h}$ under control conditions. After incubation, total RNA was isolated and the Dmt1 isoform expression and total Dmt1 expression was analyzed by

http://jme.endocrinology-journals.org DOI: 10.1530/JME-13-0261
C 2014 Society for Endocrinology Printed in Great Britain
qRT-PCR with specific primers. The expression levels were normalized to the housekeeping gene $\beta$-actin and the expression level of each Dmt1 isoform or the total Dmt1 expression under control conditions was set as $100 \%$. Data are mean \pm s.E.M. from 4 to 14 individual experiments. $* P<0.05, * * P<0.01$ compared with the control incubation. 
isoform expression approximately threefold, similar to the induction after $24 \mathrm{~h}$ hypoxia alone. The expression of all other investigated isoforms and the total Dmt1 expression were $\sim 30-50 \%$ higher after $24 \mathrm{~h}$ hypoxia followed by $6 \mathrm{~h}$ normoxic incubation, but not significantly different from the control values (Fig. 2).

\section{Effects of pro-inflammatory cytokines on Dmt1 gene expression in insulin-producing RINm5F cells}

In earlier studies, we could show that the production of ROS, especially of hydroxyl radicals, is a central element in the cytokine-mediated destruction process of insulinproducing cells (Gurgul-Convey et al. 2011, Mehmeti et al. 2011a). Therefore, the effects of pro-inflammatory cytokines on the different Dmt1 isoforms were investigated. Both, IL1 $\beta$ and a mixture of pro-inflammatory cytokines, consisting of IL1 $\beta, T N F \alpha$ and IFN $\gamma$, caused a fivefold induction of the $1 \mathrm{~A}$ and a 1.5 -fold induction of the $1 \mathrm{~B}$ isoform expression after $6 \mathrm{~h}$ incubation. After $24 \mathrm{~h}$, the IL1 $\beta$ - and cytokine mixture-mediated increase in the expression of $1 \mathrm{~A}$ isoform was already 20 -fold and further increased to 40 -fold after the $48 \mathrm{~h}$ treatment. An increase in the expression of $1 \mathrm{~B}$ isoform was also observed, although the induction was lower than that of the $1 \mathrm{~A}$ isoform (threefold after $24 \mathrm{~h}$ and fourfold after $48 \mathrm{~h}$ incubation; Fig. 3).

Parallel to the changes in expression of the $1 \mathrm{~B}$ isoform, the IRE-containing mRNA variant showed a 2.5- to 3-fold increase after $6 \mathrm{~h}$ incubation with IL1 $\beta$ alone and the cytokine mixture. However, thereafter the gene expression increase was ten- and 14-fold, respectively, after 24 and $48 \mathrm{~h}$ incubation with pro-inflammatory cytokines. The expression of the -IRE isoform was enhanced threefold after $6 \mathrm{~h}$, sixfold after $24 \mathrm{~h}$, and eightfold after $48 \mathrm{~h}$ incubation with both IL1 $\beta$ alone and the cytokine mixture.
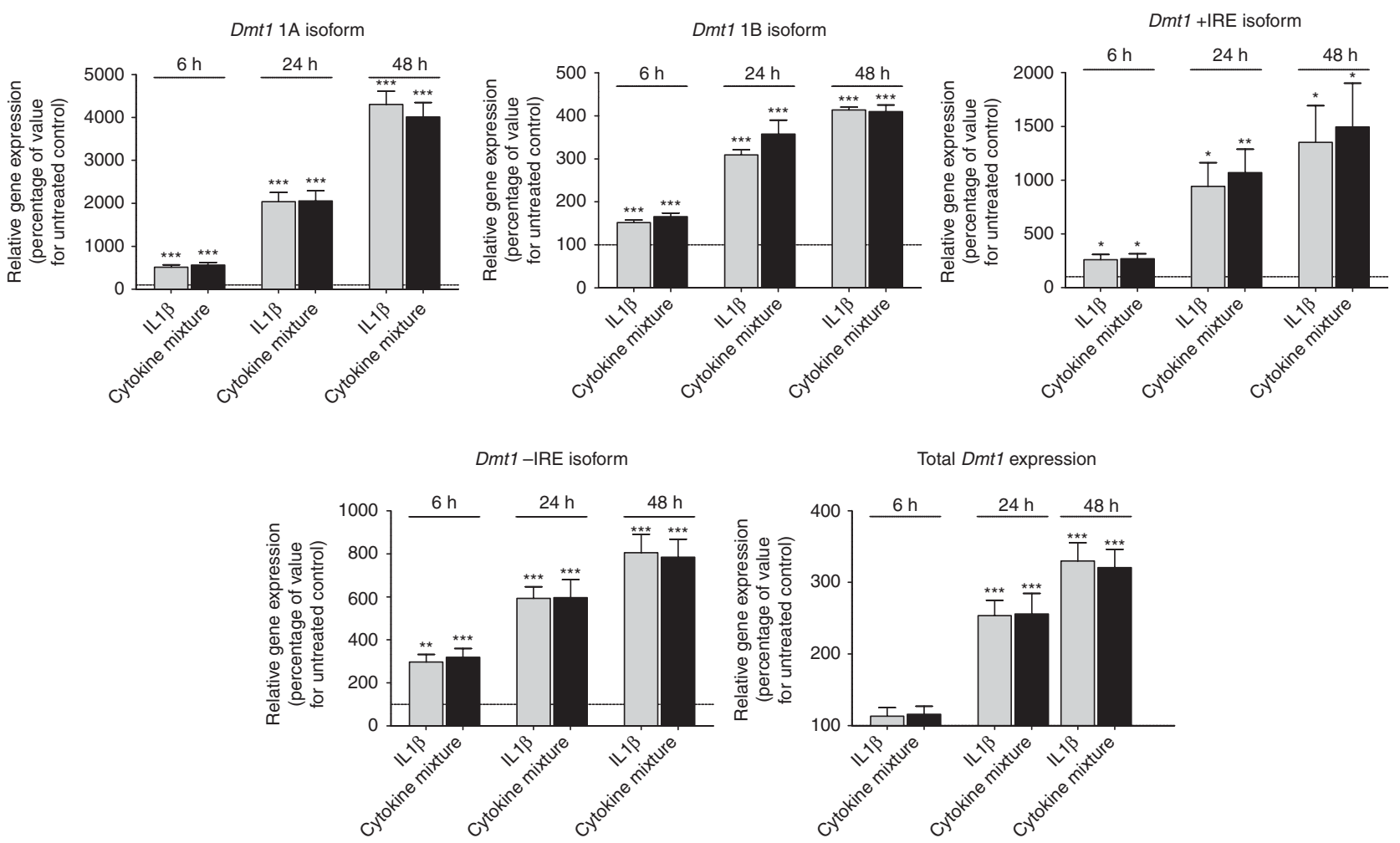

Figure 3

Effects of pro-inflammatory cytokines on the Dmt1 gene expression in insulinproducing RINm5F cells. RINm5F cells were incubated for $24 \mathrm{~h}$ with IL1 $\beta$ $(600 \mathrm{U} / \mathrm{ml})$ alone (grey bars) or a cytokine mixture (IL1 $\beta 60 \mathrm{U} / \mathrm{ml}$, TNF $\alpha 185 \mathrm{U} / \mathrm{ml}$, IFN $\gamma 14 \mathrm{U} / \mathrm{ml}$, black bars). After incubation, total RNA was isolated and the $D m t 1$ isoform expression and total Dmt1 expression was analyzed by qRT-PCR with specific primers. The expression levels were normalized to the housekeeping gene $\beta$-actin and the expression level of each $D m t 1$ isoform or the total Dmt1 expression under control conditions was set as $100 \%$. Data are mean \pm S.E.M. from five to six individual experiments. ${ }^{\star} P<0.05,{ }^{*} P<0.01, * * * P<0.005$ compared with the control incubation. 
These changes resulted also in a significantly increased total Dmt 1 expression, by 2.5 -fold after $24 \mathrm{~h}$ and 3.3-fold after $48 \mathrm{~h}$ of cytokine treatment (Fig. 3).

\section{Effects of different pro-inflammatory cytokines on Dmt1 gene expression in insulin-producing INS-1E cells}

To investigate the role of the different pro-inflammatory cytokines in the induction of the Dmt1 expression, INS-1E cells were incubated with the different cytokines alone or in two different combinations, namely IFN $\gamma$ together with TNF $\alpha$ and IL1 $\beta$ together with TNF $\alpha$ and IFN $\gamma$. The expression pattern of all investigated Dmt1 isoforms and the total Dmt1 expression in response to the employed cytokines were similar, although the expression levels were different (Fig. 4).

IL1 $\beta$ alone or the complete cytokine mixture, containing IL1 $\beta, \mathrm{TNF} \alpha$, and IFN $\gamma$, caused the highest induction up to 12.5 -fold for the Dmt1 $1 \mathrm{~A}$ isoform and 5.5-fold for the + IRE isoform. In contrast, exposure of INS-1E cells to TNF $\alpha$ or IFN $\gamma$ alone did not change the expression of any Dmt1 isoform or the total Dmt1 expression significantly. The mixture of both cytokines (TNF $\alpha$ and IFN $\gamma$ ) also did not significantly increase the Dmt1 expression. Thus, total Dmt1 expression was only (approximately 2.5-fold) induced by IL1 $\beta$ and the complete cytokine mixture $(P<0.05)$, whereas all other cytokines had no significant effects on the overall Dmt1 expression (Fig. 4). This indicates that the IL1 $\beta$ - and the cytokine mixture-induced increase in the Dmt1 expression is most probably NF- $\kappa \mathrm{B}$ mediated.

\section{Effects of pro-inflammatory cytokines on the Dmt1 protein expression in insulin-producing INS-1E cells}

To show that the cytokine-induced increase in Dmt1 gene expression results also in detectable changes in the Dmt1 protein level, the Dmt1 protein expression was analyzed by western blot analyses.
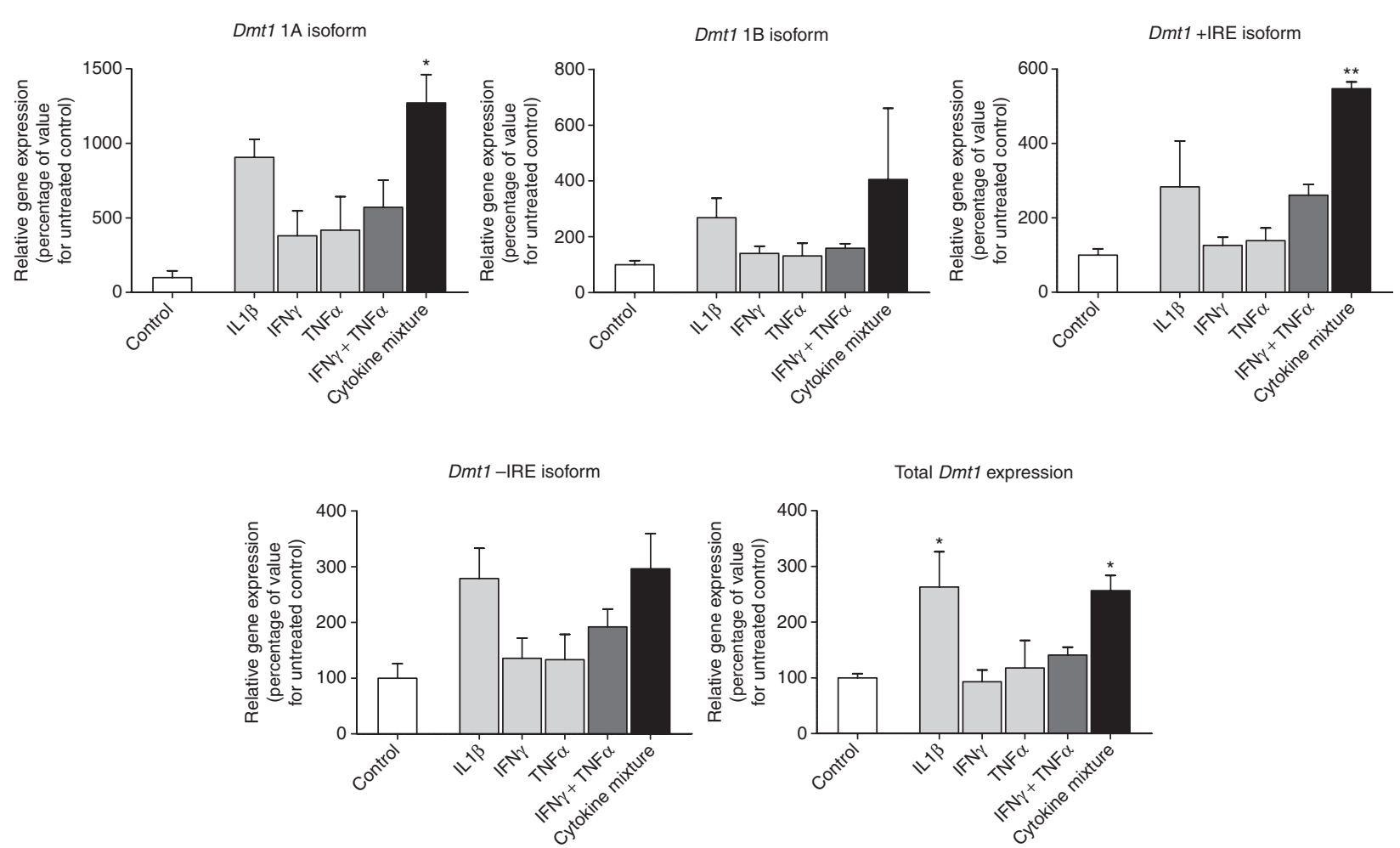

\section{Figure 4}

Effects of different pro-inflammatory cytokines on Dmt1 gene expression in insulin-producing INS-1E cells. INS-1E cells were incubated for $24 \mathrm{~h}$ under control conditions (white bars), with IL1 $\beta(600 \mathrm{U} / \mathrm{ml}), \operatorname{IFN} \gamma(140 \mathrm{U} / \mathrm{ml})$, or $\mathrm{TNF} \alpha(1850 \mathrm{U} / \mathrm{ml})$ alone (light grey bars), with IFN $\gamma(14 \mathrm{U} / \mathrm{ml})$ together with $\mathrm{TNF} \alpha(185 \mathrm{U} / \mathrm{ml}$, dark grey bars) or with the cytokine mixture (IL1 $\beta 60 \mathrm{U} / \mathrm{ml}$, $\mathrm{TNF} \alpha 185 \mathrm{U} / \mathrm{ml}$, IFN $\gamma 14 \mathrm{U} / \mathrm{ml}$, black bars). After incubation total RNA was

isolated and the Dmt1 isoform expression and total Dmt1 expression were analyzed by qRT-PCR with specific primers. The expression levels were normalized to the housekeeping gene $\beta$-actin and the expression level of each Dmt1 isoform or the total Dmt1 expression under control conditions was set as $100 \%$. Data are mean \pm s.E.M. from three individual experiments. ${ }^{\star} P<0.05, * * P<0.01$ compared with the control incubation. 
A 48-h incubation with $600 \mathrm{U} / \mathrm{ml}$ IL1 $\beta$ induced Dmt1 protein expression only slightly by $15 \%$. However, INS-1E cells exposed to the cytokine mixture showed a $33 \%$ higher Dmt1 protein expression than untreated cells $(P<0.05$, Fig. 5). After $24 \mathrm{~h}$ of incubation with cytokines, quantification of Dmt1 protein expression revealed no significant changes (data not shown).

\section{Effects of pro-inflammatory cytokines on Ft gene expression in insulin-producing RINm5F cells}

In addition to the iron import through Dmt1, iron chelation by $\mathrm{Ft}$ is another important element of intracellular iron homeostasis and the prevention of iron-catalyzed production of hydroxyl radicals. Thus, the effects of pro-inflammatory cytokines on the Ft gene

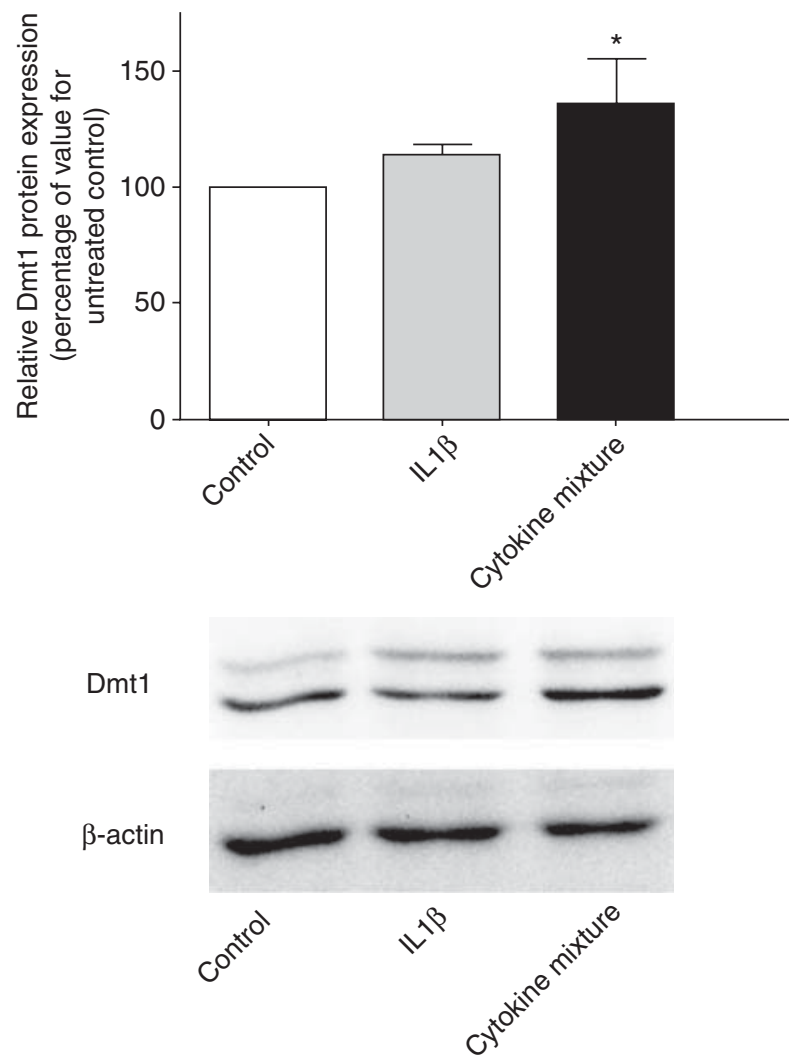

Figure 5

Effects of pro-inflammatory cytokines on Dmt1 protein expression in insulin-producing INS-1E cells. INS-1E cells were incubated for $48 \mathrm{~h}$ with IL1 $\beta(600 \mathrm{U} / \mathrm{ml})$ alone (grey bars) or a cytokine mixture (IL1 $\beta 60 \mathrm{U} / \mathrm{ml}$, TNF $\alpha$ $185 \mathrm{U} / \mathrm{ml}$, IFN $\gamma 14 \mathrm{U} / \mathrm{ml}$, black bars). After incubation protein expression of Dmt1 was quantified by western blot analysis and normalized to the housekeeping protein $\beta$-actin. Protein expression of untreated INS-1E cells was set as $100 \%$. Data are mean \pm s.E.M. from eight to ten individual experiments. ${ }^{*} P<0.05$ compared with the control incubation. expression were quantified by qRT-PCR after 8 and $24 \mathrm{~h}$ incubation.

Incubation of RINm5F cells with $600 \mathrm{U} / \mathrm{ml}$ IL1 $\beta$ had no influence on the expression of $F t$-H, Ft-L, and Mtft after 8 or $24 \mathrm{~h}$ incubation. But the cytokine mixture caused a slight significant increase (30\%) in the expression of $\mathrm{Ft}$-H after $8 \mathrm{~h}$ and a twofold increase after $24 \mathrm{~h}$ (Fig. 6A). For the Ft-L subunit after $24 \mathrm{~h}$ incubation only, a slight significant induction $(25 \%)$ was observed with the cytokine mixture (Fig. 6B), whereas for the expression of Mtft no changes after incubation with IL1 $\beta$ alone or the cytokine mixture were seen (Fig. 6C).

\section{Discussion}

Development of type 1 diabetes mellitus is associated with a progressive cellular dysfunction and damage, leading ultimately to $\beta$-cell death (Eizirik \& Mandrup-Poulsen 2001, Novotny et al. 2012). As shown in previous studies, many steps in this process are mediated by ROS including also interactions with nitric oxide (Gurgul-Convey et al. 2011). Through its extremely low half-life and its high reactivity, the hydroxyl radical is a key element in the $\beta$-cell destruction process. A high concentration of intracellular free iron behaves as a catalyst in the HaberWeiss reaction during the generation of hydroxyl radicals and can therefore contribute to cellular damage (Kehrer 2000, Halliwell \& Gutteridge 2007). The influence of $\beta$-cell toxic cytokines on the expression balance of ironimporting and intracellular chelating proteins was therefore in the focus of the present study.

Insulin-producing cell lines and primary rat islets exhibited a highly selective expression of Dmt1 1B mRNA and a slight preference for the +IRE variant. After transient hypoxia, only the weakly expressed $1 \mathrm{~A}$ isoform was induced, whereas the $1 \mathrm{~B}$ isoform was not and the expression of both 3 '-variants, +IRE and -IRE respectively, was only slightly increased. These findings are in agreement with those reported for PC12 cells (Lis et al. 2005) and highlight the role of regulatory sequences in the $5^{\prime}$ regulatory region of the Dmt1 gene as binding sites for HIF-1 $\alpha$ (Lee et al. 1998). However, due to the near absence of the expression of the $1 \mathrm{~A}$ isoform, no significant changes in total Dmt1 expression were detected, showing the limited adaption possibilities of insulin-producing cells to hypoxic conditions in contrast to other cell types (Carlsson \& Palm 2002).

Pro-inflammatory cytokines, however, were able to induce overall Dmt1 expression, as well as the expression of every single isoform significantly. Furthermore, after

Published by Bioscientifica Ltd. 

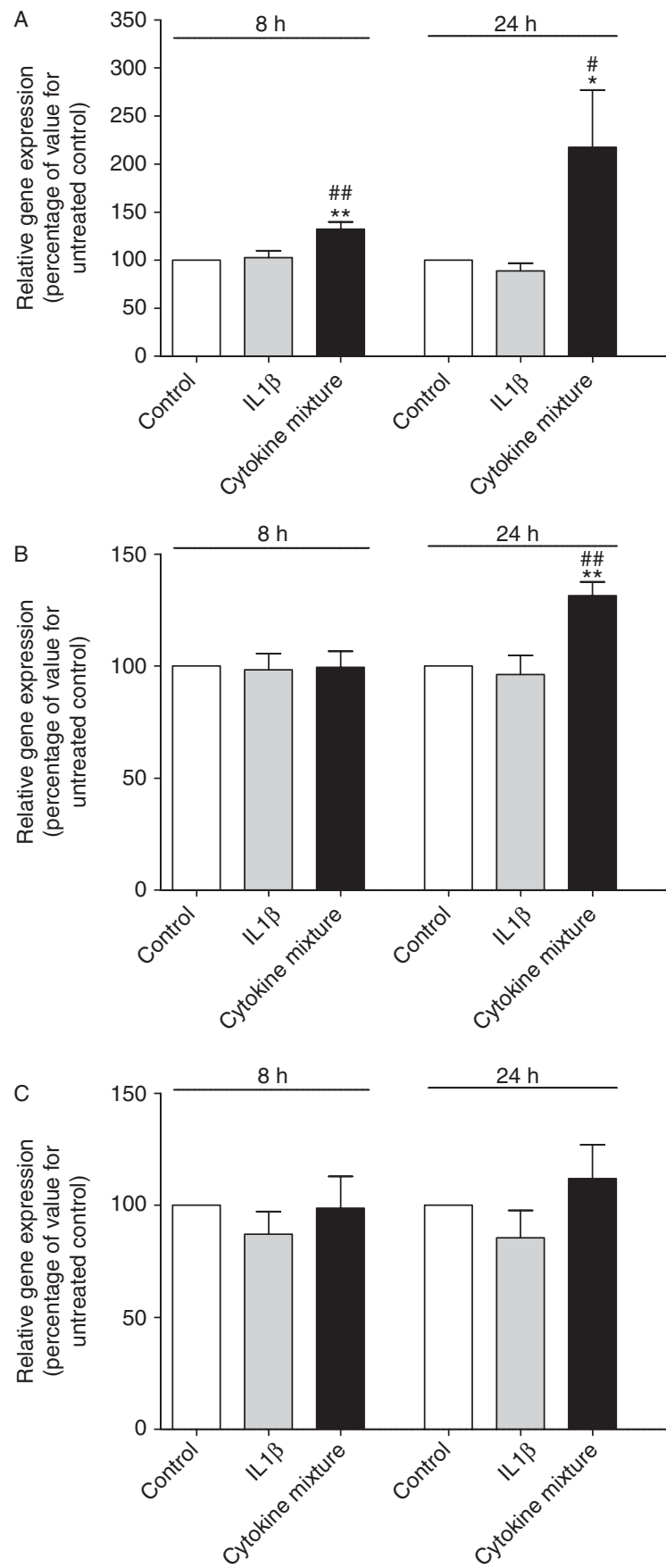

Figure 6

Effects of pro-inflammatory cytokines on Ft gene expression in insulinproducing RINm5F cells. RINm5F cells were incubated for $24 \mathrm{~h}$ under control conditions (white bars) or for 8 and $24 \mathrm{~h}$ with IL1 $\beta(600 \mathrm{U} / \mathrm{ml}$ ) alone (grey bars) and with the cytokine mixture (IL1 $\beta 60 \mathrm{U} / \mathrm{ml}$, TNF $\alpha 185 \mathrm{U} / \mathrm{ml}$, IFN $\gamma 14 \mathrm{U} / \mathrm{ml}$, black bars). After incubation total RNA was isolated and $\mathrm{Ft}$-H (A), Ft-L (B), and Mtft expression (C) was analyzed by qRT-PCR with specific primers. The expression levels were normalized to the housekeeping gene $\beta$-actin and the expression level of each $F t$ subunit under control conditions was set as $100 \%$. Data are mean \pm s.E.M. from six individual experiments. ${ }^{*} P<0.05, * * P<0.01$ compared with the control incubation; ${ }^{\#} P<0.05$, $\#$ \# $P<0.01$ compared with IL1 $\beta$ incubation.
$48 \mathrm{~h}$ also an increase in protein expression was obvious, whereas after $24 \mathrm{~h}$ a significant increase had not yet been observed. Although the delay in protein translation was unusually long, these findings are consistent with the observed kinetics of cytokine-induced cell toxicity in earlier experiments (Gurgul-Convey et al. 2011) and indicate that changes in Dmt1 mRNA expression are followed by changes in protein expression. Though the absolute gene expression level of the $1 \mathrm{~A}$ isoform was very low under control conditions, the massive induction after 24 and $48 \mathrm{~h}$ cytokine treatment could contribute to the changes in overall Dmt1 gene and protein expression and might serve also as an additional marker for cytokine-mediated changes in gene expression in insulin-secreting cells.

Further incubations with single cytokines or with selective combinations revealed the importance of IL-1 $\beta$ for the increase in the Dmt1 expression, mediated most probably by the NF- $\mathrm{B}$ signaling pathway. With these results, we could confirm the data of Hansen et al. (2012), reporting that an enhanced NF- $\kappa$ B transcriptional activity through increased Pdx1 activity potentiated cytokineinduced toxicity through upregulation of Dmt1 expression. Also in other inflammatory diseases, such as rheumatoid arthritis, an accelerated cellular iron uptake has been observed (Telfer \& Brock 2004).

A high iron transport capacity through an increased Dmt1 expression does not necessarily result in enhanced oxidative stress, because an effective chelation by $\mathrm{Ft}$ should maintain a balanced iron homeostasis and inhibit an increase of the LIP (Harrison \& Arosio 1996). However, the expression of the cytosolic Ft $\mathrm{H}$ - and L-subunits was only moderately induced after a $24 \mathrm{~h}$ incubation with the cytokine mixture, whereas the expression of the mitochondrially located $F t$ remained unchanged after incubation with cytokines. For the macrophage-derived U937 cell line it has been reported that TNF $\alpha$ and IFN $\gamma$ induced the Ft H mRNA, whereas IL1 $\beta$ showed no effect (Fahmy \& Young 1993). In addition to TNF $\alpha$ interleukin $1 \alpha$ induced also the expression of $\mathrm{Ft}$, which is in mesenchymal cells also selective for the $\mathrm{H}$-isoform (Torti et al. 1988). These reports indicate that the regulation of the Ft expression by pro-inflammatory cytokines is not unique to insulin-secreting cells, but common to many different cell types. However, in $\beta$-cells increased Dmt1 expression was associated with a higher cell death rate under pro-inflammatory conditions and suppression of Dmt1 expression by siRNA or chelation of iron under these conditions resulted in significant protection against $\beta$-cell toxic cytokines (Hansen et al. 2012), showing the

Published by Bioscientifica Ltd. 
relevance of augmented iron import and the increasing $\mathrm{Fe}^{2+}$-driven radical formation for the pathogenesis of type 1 diabetes mellitus.

The extremely low $\mathrm{H}_{2} \mathrm{O}_{2}$ inactivation capacity of insulin-secreting cells (for review, see Lenzen (2008)) goes along with a pronounced increase in Dmt1 expression and even though to a somewhat lesser extent also of iron chelation by Ft in the cytosol, which may, to a certain extent, at least neutralize increased cytokinemediated iron uptake capacity. However, such a compensation dampening ROS toxicity through increased iron binding is not possible in the mitochondria apparently, since Mtft expression did not increase under the influence of cytokines. This observation may help to explain why pro-inflammatory cytokine toxicity to the mitochondria in insulin-secreting cells has been found to be particularly prominent (Gurgul et al. 2004, Mehmeti et al. 2011a). Future studies will have to show whether iron uptake and chelation may qualify as protective targets for pharmacotherapy in the prevention of $\beta$-cell destruction in type 1 diabetes mellitus.

\section{Supplementary data}

This is linked to the online version of the paper at http://dx.doi.org/10.1530/ JME-13-0261.

\section{Declaration of interest}

The authors declare that there is no conflict of interest that could be perceived as prejudicing the impartiality of the research reported.

\section{Funding}

This work was supported by the European Union (Collaborative Project Natural immunomodulators as novel immunotherapies for type 1 diabetes (NAIMIT) in the 7th Framework Programme, Contract No. 241447).

\section{References}

Asfari M, Janjic D, Meda P, Li G, Halban PA \& Wollheim CB 1992 Establishment of 2-mercaptoethanol-dependent differentiated insulin-secreting cell lines. Endocrinology 130 167-178. (doi:10.1210/ endo.130.1.1370150)

Benhamou PY, Moriscot C, Richard MJ, Beatrix O, Badet L, Pattou F, Kerr-Conte J, Chroboczek J, Lemarchand P \& Halimi S 1998 Adenovirus-mediated catalase gene transfer reduces oxidant stress in human, porcine and rat pancreatic islets. Diabetologia 41 1093-1100. (doi:10.1007/s001250051035)

Carlsson PO \& Palm F 2002 Oxygen tension in isolated transplanted rat islets and in islets of rat whole-pancreas transplants. Transplant International 15 581-585. (doi:10.1111/j.1432-2277.2002.tb00112.x)

Chomczynski P \& Sacchi N 1987 Single-step method of RNA isolation by acid guanidinium thiocyanate-phenol-chloroform extraction.
Analytical Biochemistry 162 156-159. (doi:10.1016/00032697(87)90021-2)

Cnop M, Welsh N, Jonas JC, Jorns A, Lenzen S \& Eizirik DL 2005 Mechanisms of pancreatic $\beta$-cell death in type 1 and type 2 diabetes: many differences, few similarities. Diabetes 54 S97-107. (doi:10.2337/ diabetes.54.suppl_2.S97)

Eizirik DL \& Mandrup-Poulsen T 2001 A choice of death - the signaltransduction of immune-mediated $\beta$-cell apoptosis. Diabetologia 44 2115-2133. (doi:10.1007/s001250100021)

Fahmy M \& Young SP 1993 Modulation of iron metabolism in monocyte cell line U937 by inflammatory cytokines: changes in transferrin uptake, iron handling and ferritin mRNA. Biochemical Journal 296 175-181.

Galy B, Ferring-Appel D, Kaden S, Grone HJ \& Hentze MW 2008 Iron regulatory proteins are essential for intestinal function and control key iron absorption molecules in the duodenum. Cell Metabolism 7 79-85. (doi:10.1016/j.cmet.2007.10.006)

Greene LA \& Tischler AS 1976 Establishment of a noradrenergic clonal line of rat adrenal pheochromocytoma cells which respond to nerve growth factor. PNAS 73 2424-2428. (doi:10.1073/pnas.73.7.2424)

Gunshin H, Mackenzie B, Berger UV, Gunshin Y, Romero MF, Boron WF, Nussberger S, Gollan JL \& Hediger MA 1997 Cloning and characterization of a mammalian proton-coupled metal-ion transporter. Nature 388 482-488. (doi:10.1038/41343)

Gurgul E, Lortz S, Tiedge M, Jörns A \& Lenzen S 2004 Mitochondrial catalase overexpression protects insulin-producing cells against toxicity of reactive oxygen species and proinflammatory cytokines. Diabetes 53 2271-2280. (doi:10.2337/diabetes.53.9.2271)

Gurgul-Convey E, Mehmeti I, Lortz S \& Lenzen S 2011 Cytokine toxicity in insulin-producing cells is mediated by nitro-oxidative stress-induced hydroxyl radical formation in mitochondria. Journal of Molecular Medicine 89 785-798. (doi:10.1007/s00109-011-0747-1)

Halliwell B \& Gutteridge JMC 2007. Free Radicals in Biology and Medicine, Oxford: Oxford University Press.

Hansen JB, Tonnesen MF, Madsen AN, Hagedorn PH, Friberg J, Grunnet LG, Heller RS, Nielsen AO, Storling J, Baeyens L et al. 2012 Divalent metal transporter 1 regulates iron-mediated ROS and pancreatic $\beta$ cell fate in response to cytokines. Cell Metabolism 16 449-461. (doi:10.1016/ j.cmet.2012.09.001)

Hansen JB, Moen IW \& Mandrup-Poulsen T 2014 Iron: the hard player in diabetes pathophysiology. Acta Physiologica 210 717-732. (doi:10.1111/apha.12256)

Harrison PM \& Arosio P 1996 The ferritins: molecular properties, iron storage function and cellular regulation. Biochimica et Biophysica Acta 1275 161-203. (doi:10.1016/0005-2728(96)00022-9)

Hentze MW, Muckenthaler MU \& Andrews NC 2004 Balancing acts: molecular control of mammalian iron metabolism. Cell 117 285-297. (doi:10.1016/S0092-8674(04)00343-5)

Horowitz MP \& Greenamyre JT 2010 Mitochondrial iron metabolism and its role in neurodegeneration. Journal of Alzheimer's Disease 20 (Suppl 2) S551-S568. (doi:10.3233/JAD-2010-100354)

Hubert N \& Hentze MW 2002 Previously uncharacterized isoforms of divalent metal transporter (DMT)-1: implications for regulation and cellular function. PNAS 99 12345-12350. (doi:10.1073/pnas. 192423399)

Jörns A, Günther A, Hedrich HJ, Wedekind D, Tiedge M \& Lenzen S 2005 Immune cell infiltration, cytokine expression, and $\beta$-cell apoptosis during the development of type 1 diabetes in the spontaneously diabetic LEW.1AR1/Ztm-iddm rat. Diabetes 54 2041-2052. (doi:10.2337/diabetes.54.7.2041)

Kehrer JP 2000 The Haber-Weiss reaction and mechanisms of toxicity. Toxicology 149 43-50. (doi:10.1016/S0300-483X(00)00231-6)

Lee PL, Gelbart T, West C, Halloran C \& Beutler E 1998 The human Nramp2 gene: characterization of the gene structure, alternative splicing, promoter region and polymorphisms. Blood Cells, Molecules \& Diseases 24 199-215. (doi:10.1006/bcmd.1998.0186) http://jme.endocrinology-journals.org DOI: 10.1530/JME-13-0261 (c) 2014 Society for Endocrinology Printed in Great Britain 
Lenzen S 2008 Oxidative stress: the vulnerable $\beta$-cell. Biochemical Society Transactions 36 343-347. (doi:10.1042/BST0360343)

Lenzen S, Drinkgern J \& Tiedge M 1996 Low antioxidant enzyme gene expression in pancreatic islets compared with various other mouse tissues. Free Radical Biology \& Medicine 20 463-466. (doi:10.1016/ 0891-5849(96)02051-5)

Levi S, Corsi B, Bosisio M, Invernizzi R, Volz A, Sanford D, Arosio P \& Drysdale J 2001 A human mitochondrial ferritin encoded by an intronless gene. Journal of Biological Chemistry 276 24437-24440. (doi:10.1074/jbc.C100141200)

Lis A, Paradkar PN, Singleton S, Kuo HC, Garrick MD \& Roth JA 2005 Hypoxia induces changes in expression of isoforms of the divalent metal transporter (DMT1) in rat pheochromocytoma (PC12) cells. Biochemical Pharmacology 69 1647-1655. (doi:10.1016/j.bcp. 2005.03.023)

Lortz S, Tiedge M, Nachtwey T, Karlsen AE, Nerup J \& Lenzen S 2000 Protection of insulin-producing RINm5F cells against cytokinemediated toxicity through overexpression of antioxidant enzymes. Diabetes 49 1123-1130. (doi:10.2337/diabetes.49.7.1123)

MacKenzie EL, Iwasaki K \& Tsuji Y 2008 Intracellular iron transport and storage: from molecular mechanisms to health implications. Antioxidants \& Redox Signaling 10 997-1030. (doi:10.1089/ars.2007.1893)

Mehmeti I, Gurgul-Convey E, Lenzen S \& Lortz S 2011 $a$ Induction of the intrinsic apoptosis pathway in insulin-secreting cells is dependent on oxidative damage of mitochondria but independent of caspase-12 activation. Biochimica et Biophysica Acta 1813 1827-1835. (doi:10.1016/ j.bbamcr.2011.06.022)

Mehmeti I, Lenzen S \& Lortz S 2011b Modulation of Bcl-2-related protein expression in pancreatic $\beta$ cells by pro-inflammatory cytokines and its dependence on the antioxidative defense status. Molecular and Cellular Endocrinology 332 88-96. (doi:10.1016/j.mce.2010.09.017)

Novotny GW, Lundh M, Backe MB, Christensen DP, Hansen JB, Dahllof MS, Pallesen EM \& Mandrup-Poulsen T 2012 Transcriptional and translational regulation of cytokine signaling in inflammatory $\beta$-cell dysfunction and apoptosis. Archives of Biochemistry and Biophysics 528 171-184. (doi:10.1016/j.abb.2012.09.014)

Pantopoulos K, Porwal SK, Tartakoff A \& Devireddy L 2012 Mechanisms of mammalian iron homeostasis. Biochemistry 51 5705-5724. (doi:10.1021/bi300752r)

Telfer JF \& Brock JH 2004 Proinflammatory cytokines increase iron uptake into human monocytes and synovial fibroblasts from patients with rheumatoid arthritis. Medical Science Monitor 10 BR91-BR95.

Thomas HE, McKenzie MD, Angstetra E, Campbell PD \& Kay TW 2009 $\beta$ cell apoptosis in diabetes. Apoptosis 14 1389-1404. (doi:10.1007/ s10495-009-0339-5)

Tiedge M, Lortz S, Drinkgern J \& Lenzen S 1997 Relation between antioxidant enzyme gene expression and antioxidative defense status of insulin-producing cells. Diabetes 46 1733-1742. (doi:10.2337/ diab.46.11.1733)

Torti SV, Kwak EL, Miller SC, Miller LL, Ringold GM, Myambo KB, Young AP \& Torti FM 1988 The molecular cloning and characterization of murine ferritin heavy chain, a tumor necrosis factor-inducible gene. Journal of Biological Chemistry 263 12638-12644.

Welsh N, Margulis B, Borg LA, Wiklund HJ, Saldeen J, Flodstrom M, Mello MA, Andersson A, Pipeleers DG, Hellerstrom C et al. 1995 Differences in the expression of heat-shock proteins and antioxidant enzymes between human and rodent pancreatic islets: implications for the pathogenesis of insulin-dependent diabetes mellitus. Molecular Medicine 1 806-820.

Received in final form 5 March 2014 Accepted 10 March 2014
() 2014 Society for Endocrinology Printed in Great Britain 